\title{
Genetic investigation of XPA gene: high frequency of the c.682C $>$ T mutation in Moroccan XP patients with moderate clinical profile
}

\author{
Zineb Kindil ${ }^{1,2}$, Mohamed Amine Senhaji ${ }^{1}$, Amina Bakhchane ${ }^{1}$, Hicham Charoute ${ }^{1}$, Soumia Chihab ${ }^{3}$, \\ Sellama Nadifi ${ }^{2}$ and Abdelhamid Barakat ${ }^{1 *}$
}

\begin{abstract}
Objective: Xeroderma pigmentosum (XP) is a genetically and clinically heterogeneous disease, associated with an inherited defect in one of eight different genes (XPA to XPG and XPV). In addition to the early onset of the skin manifestations, the XP group A is marked by the presence of a mild to severe neural disorders which appear tardily and worsens with age. In this study, 9 patients with moderate clinical profile belonging to 6 XP families were recruited to determine the XPA mutational spectrum in Morocco, using the direct sequencing of the whole coding region of the XPA gene.

Results: The genetic investigation of the XPA gene showed that 7 from 9 patients were homozygous for the c.682C >T, p.Arg228X mutation, while all their investigated family members were heterozygous. The frequency of this mutation was estimated to be $83.33 \%$ (5/6 families). The molecular analysis of the 5 other exons of the XPA gene, showed that the 2 negative siblings carried no mutation in the XPA gene. This finding suggests that c.682C $>T$ (p.Arg228X) mutation is relatively associated with moderate phenotype in XP group A Moroccan families; this result will also contribute to improve the molecular diagnosis of XP disease in Moroccan patients.
\end{abstract}

Keywords: Xeroderma pigmentosum, XPA, Mutation, Morocco

\section{Introduction}

Xeroderma pigmentosum (XP) is a rare disease inherited under the autosomal recessive mode. It is clinically characterized by sunlight hypersensitivity, pigmentary changes, premature skin ageing, malignant skin and eyes tumor development $[1,2]$. This genodermatosis is responsible evenly for a markedly elevated risk of developing other skin and ocular disorders with or without neurological abnormalities [2-5]. Xeroderma pigmentosum disease shows also a high genetic heterogeneity, it has been classified into eight complementation groups $(X P A$ to $X P G$ and $X P V$ ) [6]. The $X P C, X P D$ and $X P A$

\footnotetext{
*Correspondence: hamid.barakat@pasteur.ma

${ }^{1}$ Human Molecular Genetics Laboratory, Institut Pasteur du Maroc, 1,

Place Louis Pasteur, 20360 Casablanca, Morocco

Full list of author information is available at the end of the article
}

complementation groups present the most frequent forms of Xeroderma pigmentosum in Europe, North Africa, Japan and the USA, as they are responsible for about $90 \%$ of XP patients worldwide [7]. In Japan about $60 \%$ of XP patients belong to group A, moreover, nearly $1 \%$ of Japanese population shares the (c.390-1G>C) XPA gene mutation with a founder effect [8]. The XPA human gene ensures a key role in verification of protein damage during the NER, this gene is composed of 6 exons and encodes a 273 amino acid protein which is involved in DNA excision repair pathway [9]. The XPA is a highly mutated gene, and about 32 mutations with different degree of severity have been identified [according to the Human Gene Mutation Database (HGMD): http://www. hgmd.cf.ac.uk/ac/index.php] (Table 1). This explains the fact that the XP group A patients present high 
Table 1 Number and different type of mutation in XPA human gene (The Human Gene Mutation Database: HGMD)

\begin{tabular}{lc}
\hline Mutation type & Number of mutation \\
\hline Missense/nonsense & 12 \\
Splicing & 9 \\
Regulatory & 1 \\
Small deletions & 6 \\
Small insertions & 3 \\
Small indels & 1 \\
Gross deletions & 0 \\
Gross insertions/duplications & 0 \\
Complex rearrangements & 0 \\
Repeat variations & 0 \\
Total of public mutation & 32 \\
\hline
\end{tabular}

heterogeneity of cutaneous and ocular symptoms, which are qualified as moderates comparing with the XPC group, who is known as the most severe form of Xeroderma Pigmentosum. Unlike the XP group C phenotype, $\mathrm{XP}$ group A patients present also neurological abnormalities that appeared tardily and independently from UVinduced DNA lesions $[10,11]$.

In Morocco, prevalence of the xeroderma pigmentosum is approximately $1 / 80504$, which is higher than that found in Europe and the USA [12]. Soufir et al. have reported that $X P C$ gene is the major cause of xeroderma pigmentosum in North Africa, this study showed also that the founder mutation 1643-1644delTG in XPC gene is responsible for a high proportion of XP cases [13]. This founder mutation was estimated to be responsible of more than 76\% XP in Moroccan patients [14]. To the best of our knowledge, there is no study investigating the spectrum of XPA gene mutations in the Moroccan population. Thus, 9 Moroccan patients suspected to be XP group A were analyzed; they present different degrees of severity of neuronal disorders and their age range from 7 to 33. This work aims to describe the mutation spectrum of the XPA gene in Moroccan XP patients, and clarify its involvement in molecular diagnosis of XP group A Moroccan patients.

\section{Main text \\ Methods \\ Patients}

We recruited 9 XPA patients (5 male and 4 female individuals), belonging to 6 unrelated families to describe the genetic profile of XPA diseases in Moroccan XP patients. The Classification of these patients as XP group A was based on clinical symptoms observed in almost the totality of them, including an abnormal neurological development, which worsens with age and moderate skin lesions which start earlier than neurological signs. One of our patients, a 7 years child (XP43.01) whose recruitment was based in his family history, shows no neurological disorders. Our participants all originated from different regions of Morocco and are all diagnosed and treated at the department of Dermatology in Ibn Rochd University Hospital in Casablanca.

A detailed questionnaire giving all information regarding the clinical data of each patient was filled in. An informed consent was obtained from patients as well as their relatives and was approved by the local committee on research ethics of the Pasteur Institute in Morocco.

\section{Molecular analysis}

For all patients and their relatives, the DNA extraction from whole blood was carrying out according to phenol chloroform standard protocol [15]. To disclose the presence of genetic variations in our patients, the six exons of $X P A$ gene were amplified using specific primers (Table 2). The PCRs were done in particular conditions included initial denaturation at $95^{\circ} \mathrm{C}$ for $5 \mathrm{~min}, 35$ cycles of denaturation at $94{ }^{\circ} \mathrm{C}$ for $30 \mathrm{~s}$, annealing at a specific temperature which change depending of the primer couple for $35 \mathrm{~s}$, extension at $72{ }^{\circ} \mathrm{C}$ for $40 \mathrm{~s}$, and final elongation at $72{ }^{\circ} \mathrm{C}$ for $7 \mathrm{~min}$.

PCRs were performed in $15 \mu \mathrm{l}$ final mixture volume containing 30-50 ng of DNA, 6 pmol of each primer,

Table 2 list of primers used in PCR amplification of different exons of the XPA gene

\begin{tabular}{llll}
\hline Exon & Size $(\mathbf{p b})$ & Forward primer & Reverse primer \\
\hline 1 & 430 & 5-AGAGAGCAGGTAGTTAGGCGGG & 5-CGGGGAGAGGGAAGGGGAAAG \\
2 & 320 & 5-TTGTGGACATCCTTGTGTTGTTG & 5-TGGCATTATTTAGCATCACTTTGC \\
3 & 417 & 5-GTCAGGCATTGCATACATGCTG & 5-GGCATCCTTCCTATTTTATGGGG \\
4 & 337 & 5-GCTGTGTGTGCCCCTAAGTTGC & 5-AGCAAAAGCCAAACCAATTATGAC \\
5 & 496 & 5-AGCATACGTTTACTGACAGTTTCATAGG & 5-CTTGAAGACCAACATACTGAGGGC \\
$6^{\text {a }}$ & 594 & 5_-GTGAGGTAAGAAAGTAAGTTTGCCAAG & 5_-TCTAGCACTCAGCTCCCATCTCTG \\
$6^{\text {b }}$ & 544 & 5_-GTTTCAGTGAAGGTCACCTGGC & 5_-GGTTGGTAATGCTCAGTAAATGTTAGC \\
\hline
\end{tabular}

\footnotetext{
a The first fragment of exon 6

b The second fragment of exon 6
} 
$200 \mu \mathrm{M}$ of dNTPs, $3 \mathrm{mM}$ of $\mathrm{MgCl}_{2}, 1 \times$ PCR buffer, $0.75 \mathrm{U}$ of GoTaq polymerase (Promega, Madison, USA). Purified PCR product was sequenced using the BigDye Terminator v 1.1 Standard Kit according to the manufacturer's recommendations (Applied Biosystems, Foster City, CA, USA) using ABI 3130 Genetic Analyzer.

\section{Results}

This study involved 6 unrelated XPA Moroccans families, including 9 patients. All patients developed pokilodermia as first symptom of XP at a mean age of 36 month, this pokilodermia was present in all patients' sun exposed zones (face and hand), and was more marked in patients with low sun protection, $44.44 \%$ (4/9) of our patients showed telangiectasia, and only one woman suffered from malignant tumors, she developed an non melanoma skin cancer (NMSC) at 16 years old, the Pathological analysis demonstrated an $5 \times 7.5 \times 3 \mathrm{~mm}$ basal cell carcinoma (BCC) located in the left side of the base of her nose, a later dermatoscopy examination demonstrated that she has also developed two benign tumors at 20 and 23 years old. No ocular malignancies were noticed in our patients. However five patients had photophobia and three showed keratitis in one or both eyes, one patient XP22.02 had a repetitive eye inflammation which was first diagnosed at the age of 10 years old. All our recruited patients was born with normal size and weight, an neurological abnormalities progression was shown in 8 among them; including a low sensorineural hearing loss observed in two siblings XP16.01 and XP16.02, a 33 years woman XP39.01 showed a severe mental and psychomotor retardation which progress in a loss of ability to walk, speech and motion disorders; according to her family history, two of her sisters had a typical XPA clinical profile, they also developed an progressive intellectual impairment and died in their early adulthood. Those patient's sisters hadn't been sequenced for the XPA gene, but their medical history mentioned that during their lives they developed all clinical signs characteristic of the Xeroderma pigmentosum type A. One young boy XP43.01 had a normal neurological development at the moment of his recruitment (Table 3), his family history indicate that two members of his maternal family (aunt and uncle), had a XPA clinical profile, similarly to the XP39.01 sister's, they developed a severe neurological troubles in their adulthood, before dying from cancer at the age of 29 and 34 years old respectively. The other patients aged between 12 and 18 years old had no similar antecedents in their families.

The screening of the coding region of the XPA gene disclosed the presence in homozygote state of the recurrent mutation c.682C $>\mathrm{T}$ (p.Arg228Ter) in 7/9 XP patients. This punctual variation localized in the exon 6 of the XPA gene leads to a premature termination of the encoded protein. Furthermore, all tested parents and healthy relatives of these patients were heterozygous for this mutation (Fig. 1). Additional investigation showed that 2 female siblings had no mutations in the whole XPA gene; even so they present a moderate clinical profile with mild neural retardation, this clinical feature is maybe related with molecular variations in other $X P$ gene $(X P B, X P D$ or $X P F)[16,17]$.

\section{Discussion}

Xeroderma pigmentosum is genetically and clinically heterogonous disease, its incidence was estimated at $1 / 1,000,000$ in the United States and Europe, 1/20,000100,000 in Japan $[8,16]$, and around $1 / 10,000-50,000$ in North Africa and the Middle East [17, 18]. Eight genes were identified as implicated in this rare genodermatosis among them the $X P A$ gene [6], which is characterized by neurological defects [6]. In Morocco, no data concerning the XP group A incidence is available. However in this study a clinical and mutational investigation of

Table 3 Clinical symptoms of XPA patients

\begin{tabular}{|c|c|c|c|c|c|c|c|}
\hline \multirow[t]{2}{*}{ Family code } & \multirow[t]{2}{*}{ Number of patient/family } & \multirow[t]{2}{*}{ Sex } & \multirow[t]{2}{*}{ Age } & \multirow[t]{2}{*}{ Age of first consultation (m) } & \multicolumn{3}{|l|}{ Symptoms } \\
\hline & & & & & Dermatologic & Ocular & Neurologic \\
\hline \multirow[t]{2}{*}{ XP16 } & 2 & $\mathrm{~F}$ & 31 & 84 & ++ & + & + \\
\hline & & $F$ & 32 & 72 & ++ & + & + \\
\hline \multirow[t]{2}{*}{ XP22 } & 2 & M & 15 & 60 & ++ & - & + \\
\hline & & $\mathrm{F}$ & 18 & 18 & + & + & ++ \\
\hline XP31 & 1 & $M$ & 12 & 36 & + & - & + \\
\hline \multirow[t]{2}{*}{ XP32 } & 2 & M & 14 & 72 & + & + & + \\
\hline & & $M$ & 16 & 60 & + & + & ++ \\
\hline XP39 & 1 & F & 33 & 120 & +++ & + & +++ \\
\hline XP43 & 1 & $M$ & 7 & 18 & + & - & - \\
\hline
\end{tabular}


a

Family XP43

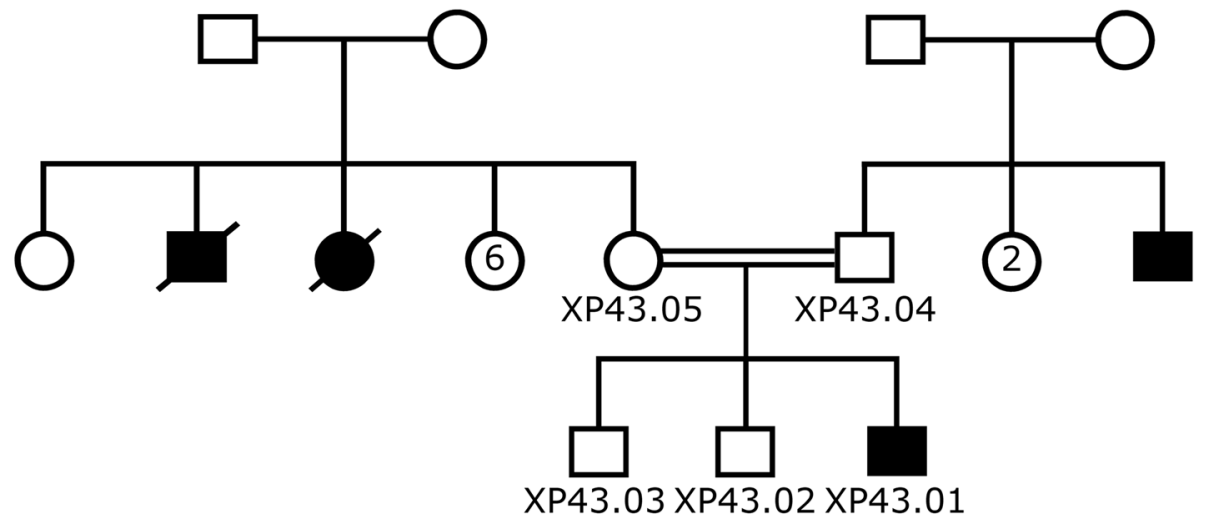

b

c.682C $>T$ (p.R280X)
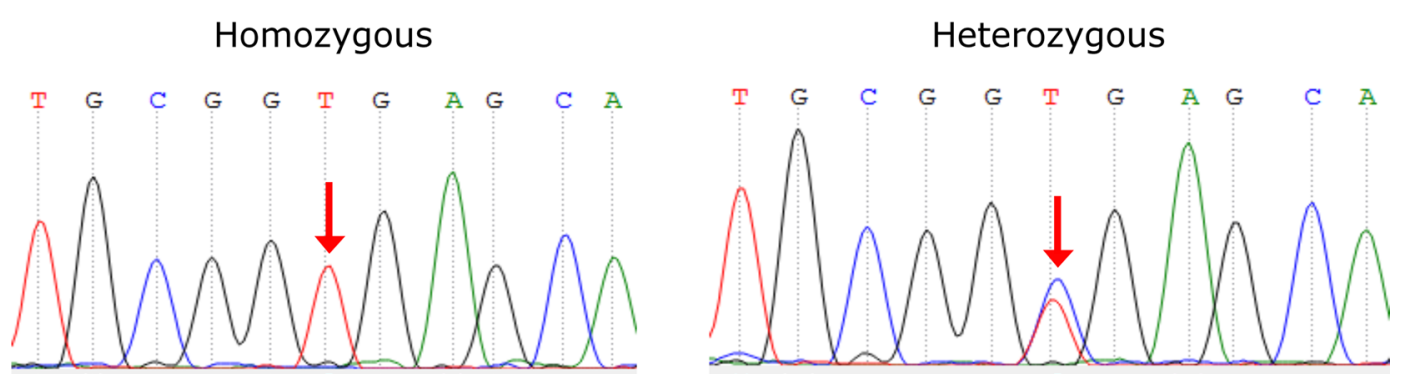

Fig. 1 a Pedigree of the family XP43. b Localization of the mutation C.682C >T (P.R228X)

$X P A$ complementation group is performed in Moroccan patients, in order to contribute to improve diagnosis for $\mathrm{XP}$ group A patients and to establish a genetic counseling for their families.

The majority of our patients $88.88 \%$ (8/9) were born from consanguineous parents; they are aged between 7 and 33 years with average age of 16.42 years. Moreover, almost all of them showed moderate skin and ocular symptoms. Neurological disorders were also observed especially in aged patients. The patient XP43.01 too young to show a mental abnormal development had a normal neurological profile.

The XPA is one of six XP protein factors overriding in human NER machinery [8]. Nowadays, over thirty mutations affecting the XPA gene had been listed at the Human Gene Mutation Database; the majority of them are Missense variations (http://www.hgmd.cf.ac.uk/ac/ index.php). The direct sequencing of the exon 6 of XPA gene showed that about $83 \%$ of screened families bear the c.682C>T (p.Arg228X) point mutation, this mutation correspond to $\mathrm{C}$ to $\mathrm{T}$ transition at position 682 of the coding DNA, and leads to a truncated protein. This nonsense mutation occurs in the C-terminal domain of XPA protein, and this could explain the moderate clinical manifestations of our XP group A patients; since the severity of the clinical phenotype is observed when mutations are located in the DNA binding region (aa 98-219) (Fig. 2). This moderate phenotype was also detected in American, European and Japanese families who are sharing this punctual mutation [19]. In Tunisia, six out of seven XP group A patients had this nonsense mutation with a frequency of $86 \%$ [20]. In addition, a previous study has shown that all XP group A Tunisian patients with moderate phenotype had this mutation with founder effect [21]. The same mutation was also identified in Algerian XP group A patients [22]. A study leading by Soufir et al. including 66 unrelated XP families from North Africa, showed that the c.682C >T (p.Arg228X) mutation was present in all XP group A analyzed patients with a frequency of $12 \%$ [13]. This suggested that this mutation may have a common founder effect in the North African region.

Severe clinical phenotype is usually observed when patients had mutations within exons $3-5$, as reported in four Egyptians [23] and one Iranian patient [24]. A very severe abnormalities were also observed in a Japanese patient who present a mutation located at intron 3 in the splice site [25]. 


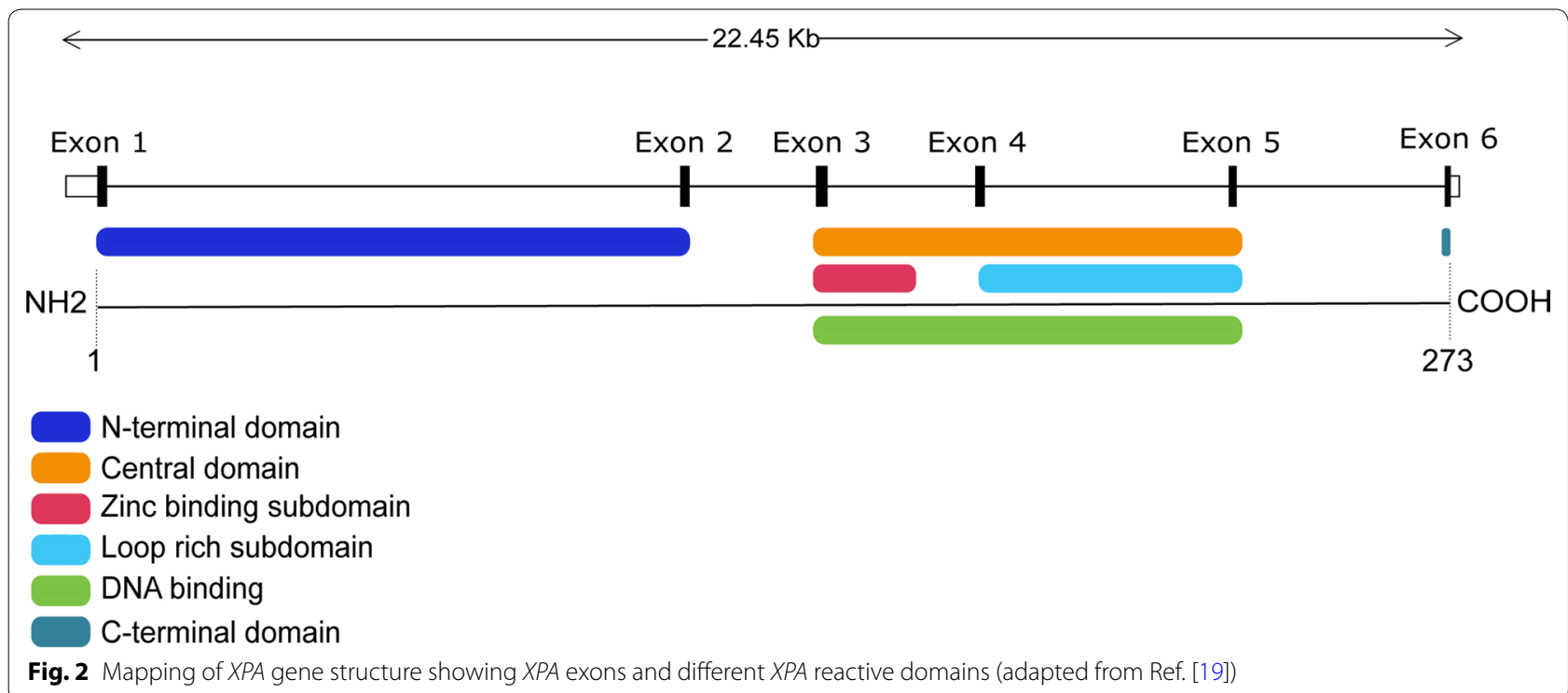

On the other hand, the molecular investigation in patients with no mutation in exon 6, has demonstrated that those two young siblings don't share any molecular variation in the others $X P A$ gene exons. As perspective, those two patients will be analyzed for the $X P B, X P D$ and $X P F$ genes responsible of rare forms of xeroderma pigmentosum with neurological disorders [26, 27].

In conclusion, our finding suggested that the c. $682 \mathrm{C}>\mathrm{T}$ (p.Arg228X) mutation is relatively associated with moderate clinical profile in XP group A Moroccan patients.

\section{Limitations}

This work in which the XPA gene were analyzed for the first time in the Moroccan population will provide a basis for the prenatal diagnosis and genetic counseling. However, the sample size is relatively small and further studies are necessary to determine the spectrum of XPA gene mutations is Moroccan patients.

\section{Abbreviations \\ BCC: basal cell carcinoma; NER: nucleotide excision repair; NMSC: melanoma skin cancer; PCR: polymerase chain reaction; XP: xeroderma pigmentosum; $X P A$ : xeroderma pigmentosum, complementation group $A ; X P C$ : xeroderma pigmentosum, complementation group $C ; X P D$ : xeroderma pigmentosum complementary group $D ; X P G$ : xeroderma pigmentosum complementary group G; XPV: xeroderma pigmentosum, variant type.}

\section{Authors' contributions}

$A B$ conceived, designed and coordinated the study. ZK performed the laboratory work. MAS helped in the laboratory work. ZK wrote the paper. AmB, HC, SC and SN participated in interpretation of results. All authors read and approved the final manuscript.

\section{Author details}

1 Human Molecular Genetics Laboratory, Institut Pasteur du Maroc, 1 , Place Louis Pasteur, 20360 Casablanca, Morocco. ${ }^{2}$ Laboratory of Genetics and Molecular Pathology, Faculty of Medicine, Hassan II University, Casablanca,
Morocco. ${ }^{3}$ Department of Dermatology, Hospital University lbn Rochd, Casablanca, Morocco.

\section{Acknowledgements}

The authors would like to express their deep gratitude to patients and their families, as well as the dermatology service members for their contribution to this work.

\section{Competing interests}

The authors declare that they have no competing interests.

Availability of data and supporting materials

Please contact Dr. Abdelhamid Barakat (hamid.barakat@pasteur.ma) for data requests.

Consent for publication

Not applicable.

\section{Ethics approval and consent to participate}

All participants signed informed consent forms. In the case of children aged less than 16 years old, we obtained parental consent. The study protocol was approved by local Committee on Research Ethics of Pasteur Institut of Morroco.

\section{Funding}

This work was supported by Institut Pasteur du Maroc.

\section{Publisher's Note}

Springer Nature remains neutral with regard to jurisdictional claims in published maps and institutional affiliations.

Received: 15 June 2017 Accepted: 30 November 2017

Published online: 06 December 2017

References

1. Butt FMA, Moshi JR, Owibingire S, Chindia ML. Xeroderma pigmentosum: a review and case series. J Cranio-Maxillo-fac Surg Off Publ Eur Assoc Cranio-Maxillo-fac Surg. 2010;38(7):534-7.

2. Tamura D, DiGiovanna JJ, Kraemer KH. Founder mutations in xeroderma pigmentosum. J Invest Dermatol. 2010;130(6):1491-3. 
3. Stary A, Sarasin A. The genetics of the hereditary xeroderma pigmentosum syndrome. Biochimie. 2002;84(1):49-60.

4. Kraemer KH, Lee MM, Scotto J. Xeroderma pigmentosum. Cutaneous, ocular, and neurologic abnormalities in 830 published cases. Arch Dermatol. 1987;123(2):241-50.

5. Sugasawa K, Ng JM, Masutani C, Iwai S, van der Spek PJ, Eker AP, et al. Xeroderma pigmentosum group $\mathrm{C}$ protein complex is the initiator of global genome nucleotide excision repair. Mol Cell. 1998;2(2):223-32.

6. Lehmann AR. DNA repair-deficient diseases, xeroderma pigmentosum, Cockayne syndrome and trichothiodystrophy. Biochimie. 2003:85(11):1101-11.

7. Legerski R, Peterson C. Expression cloning of a human DNA repair gene involved in xeroderma pigmentosum group C. Nature. 1992;359(6390):70-3.

8. Hirai Y, Kodama Y, Moriwaki S-I, Noda A, Cullings HM, Macphee DG, et al. Heterozygous individuals bearing a founder mutation in the XPA DNA repair gene comprise nearly $1 \%$ of the Japanese population. Mutat Res. 2006:601(1-2):171-8.

9. Legerski RJ, Liu P, Li L, Peterson CA, Zhao Y, Leach RJ, et al. Assignment of xeroderma pigmentosum group C (XPC) gene to chromosome 3p25. Genomics. 1994;21 (1):266-9.

10. Laposa RR, Cleaver JE. DNA repair on the brain. Proc Natl Acad Sci USA. 2001;98(23):12860-2.

11. Ben Rekaya M, Messaoud O, Talmoudi F, Nouira S, Ouragini H, Amouri A, et al. High frequency of the V548A fs X572 XPC mutation in Tunisia: implication for molecular diagnosis. J Hum Genet. 2009;54(7):426-9.

12. Doubaj Y, Laarabi F-Z, Chafai Elalaoui S, Barkat A, Sefiani A. Carrier frequency of the recurrent mutation c.1643_1644deITG in the XPC gene and birth prevalence of the xeroderma pigmentosum in Morocco. $J$ Dermatol. 2012;39(4):382-4.

13. Soufir N, Ged C, Bourillon A, Austerlitz F, Chemin C, Stary A, et al. A prevalent mutation with founder effect in xeroderma pigmentosum group $C$ from north Africa. J Invest Dermatol. 2010;130(6):1537-42.

14. Senhaji MA, Abidi O, Nadifi S, Benchikhi H, Khadir K, Ben Rekaya M, et al. c.1643_1644delTG XPC mutation is more frequent in Moroccan patients with xeroderma pigmentosum. Arch Dermatol Res. 2013;305(1):53-7.

15. Grimberg J, Nawoschik S, Belluscio L, McKee R, Turck A, Eisenberg A. A simple and efficient non-organic procedure for the isolation of genomic DNA from blood. Nucleic Acids Res. 1989;17(20):8390

16. Moriwaki S, Kraemer KH. Xeroderma pigmentosum-bridging a gap between clinic and laboratory. Photodermatol Photoimmunol Photomed. 2001;17(2):47-54.
17. Cartault F, Nava C, Malbrunot A-C, Munier P, Hebert J-C, N'Guyen P, et al. A new XPC gene splicing mutation has lead to the highest worldwide prevalence of xeroderma pigmentosum in black Mahori patients. DNA Repair Amst. 2011;10(6):577-85.

18. Zghal M, El-Fekih N, Fazaa B, Fredj M, Zhioua R, Mokhtar I, et al. Xeroderma pigmentosum. Cutaneous, ocular, and neurologic abnormalities in 49 Tunisian cases. Tunis Méd. 2005:83(12):760-3.

19. States J, McDuffie E, Myrand S, McDowell M, Cleaver J. Distribution of mutations in the human xeroderma pigmentosum group A gene and their relationships to the functional regions of the DNA damage recognition protein. Hum Mutat. 1998;12(2):103-13.

20. Nishigori C, Zghal M, Yagi T, Imamura S, Komoun MR, Takebe H. High prevalence of the point mutation in exon 6 of the xeroderma pigmentosum group A-complementing (XPAC) gene in xeroderma pigmentosum group A patients in Tunisia. Am J Hum Genet. 1993;53(5):1001-6.

21. Messaoud O, Ben Rekaya M, CherifW, Talmoudi F, Boussen H, Mokhtar I, et al. Genetic homogeneity of mutational spectrum of groupA xeroderma pigmentosum in Tunisian patients. Int J Dermatol. 2010;49(5):544-8

22. Bensenouci S, Louhibi L, De Verneuil H, Mahmoudi K, Saidi-Mehtar N. Diagnosis of xeroderma pigmentosum Groups $\mathrm{A}$ and $\mathrm{C}$ by detection of two prevalent mutations in West Algerian population: a rapid genotyping tool for the frequent XPC mutation c.1643_1644delTG. BioMed Res Int. 2016. Disponible sur: http://www.ncbi.nlm.nih.gov/pmc/articles/ PMC4931069/. Accessed 18 Jul 2017.

23. Amr K, Messaoud O, El Darouti M, Abdelhak S, El-Kamah G. Mutational spectrum of xeroderma pigmentosum group A in Egyptian patients. Gene. 2014;533(1):52-6.

24. Ghafouri-Fard S, Fardaei M, Miryounesi M. A novel 5 nucleotide deletion in XPA gene is associated with severe neurological abnormalities. Gene. 2016;576(1, Part 2):379-80.

25. Nishigori C, Moriwaki S, Takebe H, Tanaka T, Imamura S. Gene alterations and clinical characteristics of xeroderma pigmentosum group A patients in Japan. Arch Dermatol. 1994;130(2):191-7.

26. Dupuy A, Sarasin A. DNA damage and gene therapy of xeroderma pigmentosum, a human DNA repair-deficient disease. Mutat Res. 2015:776:2-8.

27. Moriwaki S, Nishigori C, Imamura S, Yagi T, Takahashi C, Fujimoto N, et al. A case of xeroderma pigmentosum complementation group $\mathrm{F}$ with neurological abnormalities. Br J Dermatol. 1993;128(1):91-4.

\section{Submit your next manuscript to BioMed Central and we will help you at every step:}

- We accept pre-submission inquiries

- Our selector tool helps you to find the most relevant journal

- We provide round the clock customer support

- Convenient online submission

- Thorough peer review

- Inclusion in PubMed and all major indexing services

- Maximum visibility for your research

Submit your manuscript at www.biomedcentral com/submit
BioMed Central 